\title{
Online Learning Model Development Based on Blended Learning to Increase Activity and Learning Result
}

\author{
Rosmaria, Darmansyah, Ramalis Hakim \\ Universitas Negeri Padang \\ mariaros788@gmil.com
}

\begin{abstract}
This research aimed to reveal: how the process of developing online learning model based on blended learning on valid class action research courses (PTK) is valid, how the practice of online learning model based on blended learning in the course of PTK? How the effectiveness of the development of online learning model based on blended learning on the course of PTK ? The source of this research data was students majoring in Curriculum and Educational Technology State University of Padang on lecture PTK, in the form of questionnaire validity, practicality, and effectiveness. The results of this study were found from the validity of 3 aspects of media, materials, and language. Then test the lecturer's responsiveness and student response. While the effectiveness test has seen from the results of learning and student learning activities. The average product validity category is very valid, the average of the practicality of student responses practical category. The average practice of lecturer respond is practical category. While the effectiveness test result of student learning result obtained average category very effective and student activity value ategory very effectively. Based on the above data can be concluded that the online learning model based on blended learning in the course of PTK valid, practical, and effective use in lecturing process
\end{abstract}

Keywords-Online Learning Model; Blended Learning; classroom action research

\section{INTRODUCTION}

The field of Education Technology studies requires the provision of various learning resources in the learning process. Ganefri, (2017) stated that Padang State University should implement instructional development by incorporating various strategies in learning, and the need for technology is an important part of the learning process itself.

In accordance with the Law of National Education Number 20 the Year 2003 (UU SPN Number 20 of 2003) that the national education role to develop the ability and shape the character and civilization of dignified nation in order to educate the nation. In line with the change of learning, a paradigm is reinforced by the government regulation No. 32 of 2013, that the success of teaching and learning activities in universities is not only determined by the lecturer faculty course but is strongly influenced by the liveliness of students or known as the Student- Centered Learning.

The Learning process that happened so far in lecturing PTK not yet fulfill the learning criteria mentioned in Government Regulation Number 32 the Year 2013. Based on observation, dated 05 March 2018 in the curriculum and technology department of Education Faculty of the State University of Padang toward students who follow PTK lecture. In the learning process, students still do not understand well the lecture material of PTK. When the assignment, the completion has not met the requirements of the task and systematics of writing a PTK proposal. This is evidenced by the number of students who are on the standard of graduation, which is 59, (UNP, 2018).

PTK lecture materials require more discussion between students and lecturers to understand how to do planning, implementation, and evaluation in PTK. Therefore, PTK lecture time for one meeting is not enough with only 2 credits. Many things that can cause problems in lectures to occur, one of which is the use of learning models that have not been right in the lecture PTK. While implementing a structured learning model and having concrete learning activities steps will improve the quality of learning.

Based on these explanations, found a solution that can be used in overcoming the problems in the course of PTK, namely by developing online learning model. Strategies that can be applied to online learning is indirect learning (Asynchronous) and direct learning (Synchronous) (Prawiradilaga, 2013, p. 110). Online learning model requires the ability of learners in the implementation of learning. online learning has the potential to be used to complement or replace face-to-face lectures or traditional learning. (Hastjarjo, 2009, p. 172).

The reason for using online learning model based on blended learning, because not all lecture material can be done online, but can be done online and face to face. Blended learning is a blend of face-to-face learning and online learning. Blended learning (a combination of face-to-face and online teaching and learning) is part of a learning innovation, especially in the development of a challenging world as an effective innovation in teaching and learning. Alammary, et al, (2014, p.441), says there are four concepts in the definition of blended learning. First, combining or mixing Web-based technology modes (such as direct virtual Classroom, fast-paced instruction, collaborative learning, 
streaming video, audio, and text) to achieve educational goals. Second, incorporate various pedagogical approaches (eg, constructivism, behaviorism, cognitivism) to produce optimal learning outcomes with or without instructional technology. Third, it combines all forms of instructional technology (such as Videotape, CD-ROM, Web-based training, movies) with face-to-face instructor-led training. Fourth, mix or incorporate instructional technology with actual job assignments to create harmonious learning and work effects.

Research related to online learning model has been done by Ni (2013) a face-to-face meeting and online learning in MPA program at California State University-San Bernardino. This finding has some implications for student learning, course development, and curriculum design. Online interaction can be used to improve learning, especially for students who tend to be less active in the classroom. Furthermore, Nguyen (2015) conducted a study on the online learning website http://www.nosignificantdifference.org with the results of the study that $92 \%$ of all distance and online education studies are as effective as traditional education, than $3 \%$ of data found that face to face (traditional) is better and about 4\% shows mixed findings. Furthermore, Muchlas (2013) with the results of the multimedia validation of the model developed from the five aspects of validation, resulted in an average error of $87.5 \%$, which shows the product is very feasible to implement. Wulandari (2014) with the results of expert media validation of the product being carried out after using online learning media products based on this application and the results in 4.33 in the aspect of appearance and 4.33 in the programming aspect. Tiara (2015) conducted a study of Moodle-based online learning with the average validation results by experts at $97 \%$ with very reasonable interpretation criteria. Based on the validity of developing blended learning online learning models and previous research, the online learning model in the category is very valid and can be used in the learning process.

Based on the above description, the problem to be studied in this article is the development of online learning model based on blended learning for classroom action research in the State University of Padang. The difference in this study with previous research is on the object of research. The purpose of this assessment is seen from two aspects, namely the development of online learning model based on blended learning and increasing student activity and learning outcomes. This online learning model is developed in the form of a learning website that contains e-book courses, group discussions, live streaming lectures and evaluation questions.

\section{METHODS}

This research uses research and development ( $R$ \& D) method. The data in this research was taken through validation questionnaire, a questionnaire of practicality, student learning result, and student activity observation sheet. Research subjects were students majoring in Education Technology even semester January-June 2018, This research development process is to develop a product in the form of online learning model based on blended learning communicative in making learning website as a medium in learning. The development procedure was done in several stages: (1) analysis phase; (2) design stage; (3) development stage; (4) implementation stage (implementation); and (5) evaluation stage (evaluate). This development model was adapted from the ADDIE instructional design model, (Beni, 2010).

First, the analysis phase analyzed the need for the development of online learning model and analyze the feasibility and requirements of model development. Secondly, the design phase is designed to model the development of online learning model, This activity was a systematic process. This stage of the design has been prepared conceptual framework of the application of the model of development of online learning model. Third, the development stage (development) contains activities of product design realization of the development of online learning model. Fourth, the implementation stage (implementation) was done by the implementation of the design and method that has been developed in a real situation that was in class. Fifth, the evaluation phased (evaluate) is done in two forms: a formative and summative evaluation. Formative evaluation is conducted at the end of each meeting, while summative evaluation is performed after the activity ends in its entirety. Summative evaluation measures the final competencies of the course or the learning objectives to be achieved.

\section{FINDING AND DISCUSSION}

After the stages of development based on ADDIE model is done then obtained the validity, practicality, and effectiveness of online learning model based on blended learning. The results of the research are described as follows.

\section{Analysis (Analysis)}

1.1.1. Needs analysis

1.1.1.1. Curriculum analysis

Curriculum analysis was conducted to find out the development of online learning model based on blended learning in the course of research of class action (PTK). Based on the instructional analysis and the syllabus of PTK course, it is necessary to increase the time for the course of PTK. However, because it does not allow to add 2 credits to 3 credits or 4 credits with the reason for the curriculum change in the Education Technology course is complicated if done. Then in tactics with the implementation of the online learning model. On the online learning is done the method of live material exposure and discussion online and on face to face consultation task and lecture information. 


\subsubsection{Student analysis}

Student analysis is done because it is one of the first steps in learning planning. Student analysis is done to analyze student requirement, student characteristic, analyze student ability in facing problem in lecturing process. Furthermore, an analysis of the main subjects that will be developed as a teaching language to be in accordance with the implementation of the lecture.

Students who follow the course of PTK already have a schematic how to use the computer, accessing the Web learning, assuming students can already use the computer to access the website because it is accustomed to searching for lecture material on the internet. other than that student who has different characteristics, especially in terms of learning styles, both visual, audio and kinesthetic filled with various things according to the needs of student learning styles. For students with visual learning styles presented learning videos and written materials that have been well designed by lecturers mentor courses and can be downloaded by students. Live video learning can meet the needs of students who have learning style of audio students. While the field practice, giving tasks and direct guidance to lecturers for students with learning styles kinesthetic.

1.1.1.3. Feasibility analysis.

In the online learning developed learning website that will be implemented by utilizing the Internet network in the implementation of learning in order to improve the quality of learning that usually only rely on face-to-face meetings only.

Based on curriculum analysis, student analysis, and feasibility analysis, the online learning model based on blended learning can be used in lecturing process.

1. Design

The Online learning model is designed to build a learning system with E-Learning concept (e-learning) or Distance Learning (Distance Learning). This concept makes the teaching and learning system will not be limited in space and time. A lecturer can provide course material from anywhere. Likewise, a student can attend a lecture from anywhere. Even the process of test or quiz activities can be done remotely.

2. Developt

The development of online learning model is done based on requirement analysis that has been done before, that is a development of online learning at PTK lecture. The goal is that online learning developed can be accessed by students from the computer as a space for learning process and communication of students and lecturers that is practical and easy that can be accessed anytime and anywhere, so that students are motivated to access learning materials and information related to learning materials without having to spend a lot of time. The level of students' understanding of the lecture material is better because the students choose to actively follow the lecture lesson about the material being studied.

At the development stage validation of online learning model based on blended learning. Validation of online learning model is done on 3 aspects, namely material aspect, model aspect and language aspect. Validation is assessed by 3 experts, ie material experts, media experts, and linguists. Here is the percentage of material validation of online learning model based on blended learning. 
Table 1. Percentage of Material Validation

\begin{tabular}{clccc}
\hline Number & \multicolumn{1}{c}{ Aspect } & Amount (\%) & Category \\
\hline 1 & $\begin{array}{l}\text { The material on learning in the online learning } \\
\text { model is presented systematically }\end{array}$ & 100 & very practical \\
\hline 2 & $\begin{array}{l}\text { The material on online learning is presented } \\
\text { logically }\end{array}$ & 100 & very practical \\
\hline 3 & $\begin{array}{l}\text { The instructions for using the online learning } \\
\text { model are clear }\end{array}$ & 100 & very practical \\
\hline 4 & $\begin{array}{l}\text { The material on the online learning model bias is } \\
\text { studied independently }\end{array}$ & 100 & very practical \\
\hline 5 & $\begin{array}{l}\text { Students are assumed able to use instructional } \\
\text { media used in this learning model }\end{array}$ & 100 & very practical \\
\hline 6 & $\begin{array}{l}\text { The material presented in complete learning } \\
\text { online learning }\end{array}$ & 100 & very practical \\
\hline 7 & Problems used in accordance with SAP & 100 & very practical \\
\hline 8 & $\begin{array}{l}\text { Tasks used in accordance with SAP subject } \\
\text { matter }\end{array}$ & $\begin{array}{l}\text { The questions on online learning can be used as a } \\
\text { student training tool at home }\end{array}$ & 100 & very practical \\
\hline 9 & & 900 & \\
\hline amount & & 100 & \\
\hline category & & &
\end{tabular}

Based on validation results by material expert's validator, the material on the online spinning model is very practical for the lecture PTK. Furthermore, validation by an expert model of learning with validation results as follows.

Table 2. Percentage Validation of Online Learning Model

\begin{tabular}{clcc}
\hline Number & \multicolumn{1}{c}{ Aspect } & Amount $(\%)$ & Category \\
\hline 1 & syntax & 85 & very practical \\
\hline 2 & Social system & 90 & very practical \\
\hline 3 & Support system & 96,9 & very practical \\
\hline 4 & SAP & 89,2 & very practical \\
\hline 5 & Evaluation & 95,8 & very practical \\
\hline 6 & principle of reaction & 87,5 & very practical \\
\hline amount & & \multicolumn{3}{c}{544,4} \\
\hline Average & & \multicolumn{3}{c}{ very practical } \\
\hline category & & \multicolumn{3}{c}{}
\end{tabular}

Based on the validation results by the expert model of the learning model, the online sponsorship model is very practical for the lecture PTK. Next is validation by linguists based on correct EYD method. 
Table 3. Language Validation of Online Learning Models

\begin{tabular}{|c|c|c|c|}
\hline Number & Aspect & Amount (\%) & Category \\
\hline 1 & $\begin{array}{l}\text { The language used according to } \\
\text { EYD in Indonesian grammar rule }\end{array}$ & 75 & practical \\
\hline 2 & $\begin{array}{l}\text { Sentences used are easy to } \\
\text { understand }\end{array}$ & 75 & practical \\
\hline 3 & The sentence used is not ambiguous & 75 & practical \\
\hline 4 & The language used is already & 100 & very practical \\
\hline 5 & $\begin{array}{l}\text { Sentences used are easy to } \\
\text { understand for self-learning }\end{array}$ & 75 & practical \\
\hline 6 & $\begin{array}{l}\text { The use of simple language so that } \\
\text { messages from the subject matter are } \\
\text { delivered }\end{array}$ & 100 & very practical \\
\hline 7 & $\begin{array}{l}\text { The terms used are consistent so } \\
\text { they are easy to unde }\end{array}$ & 75 & practical \\
\hline 8 & $\begin{array}{l}\text { Kalimat petunjuk soal evaluasi } \\
\text { mudah dipahami }\end{array}$ & 75 & practical \\
\hline jumlah & & \multicolumn{2}{|c|}{650} \\
\hline Average & & \multicolumn{2}{|c|}{81,25} \\
\hline category & & \multicolumn{2}{|c|}{ very practical } \\
\hline
\end{tabular}

The number of scores obtained then summed and averaged so as to obtain the value of the validity of $90.97 \%$. Referring to the category of criteria of validity, then the validity of the learning model included in the category is very valid. After the online learning model based on blended learning stated valid, then the next step is to see the practicality of the online learning model based on blended learning developed. A practical model of online learning based on blended learning is related to modeling by students and lecturers.

A practical model of online learning based on blended learning is obtained after the implementation of small group evaluation, and field test (large group test). Small group evaluation consists of 5 (five) students who are heterogeneous. The amount of practicality value obtained from 5 students covering 10 aspects of assessment is $83.5 \%$.

Table 4. Percentage of Small Group Practice Test

\begin{tabular}{llccc}
\hline Number & \multicolumn{1}{c}{ Aspect } & Item & Percentage & Information \\
\hline 1 & View & $1-3$ & 81,7 & very practical \\
\hline 2 & $\begin{array}{l}\text { Presentation of } \\
\text { material }\end{array}$ & 4 & 80 & practical \\
\hline 3 & fidelity & $5-10$ & 85 & very practical \\
\hline
\end{tabular}

Referring to the category of practicality criterion, the result of small group testing practice is included in the very practical category. The next evaluation is a large group evaluation. The following test results of the practice of large group testing.

Table 5. Percentage of Large Group Practice Test

\begin{tabular}{|c|c|c|c|c|}
\hline Number & Aspect & Item & Percentage & Information \\
\hline 1 & View & $1-3$ & 79,375 & practical \\
\hline 2 & $\begin{array}{l}\text { Presentation } \\
\text { material }\end{array}$ & 4 & 81,25 & very practical \\
\hline 3 & fidelity & $5-10$ & 80,625 & very practical \\
\hline
\end{tabular}

Evaluation of the practice of large group test conducted by 40 students covering 10 aspects of the assessment is $80.31 \%$ with the practical category. Furthermore, the effectiveness test on the learning outcomes done is $86.00 \%$ with the very effective category. Next is the result of student activity observation with a score of $90.0 \%$ with a very good category. The following table shows the results of student activity observation of online learning model based on blended learning. 
Table 6. Observation Result of Student Activity

\begin{tabular}{cccc}
\hline Visual & Listening & motor activity & Emotional \\
\hline 15 & 4 & 4 & 13 \\
\hline 93,75 & 100 & 100 & 81,25 \\
\hline SB & SB & SB & SB \\
\hline
\end{tabular}

Based on the above effectiveness test results can be concluded that effective online learning model used by students in improving learning outcomes and learning activities. Other studies also corroborate the results of research on the effectiveness of the online learning model is the research conducted Wulandari (2015) with the results of research, test the feasibility of materials experts get average score 4.11 with very good category, the results of expert media assessment get the average score 4.28 with very good category, and the results of the trial users get an average score of 4.09 with very good category.

\section{Implement}

At this stage do the implementation / utilizing the online learning model in the learning activities. The results of the development are applied in the learning to know the effect on the quality of learning which includes the effectiveness, attractiveness, and efficiency of learning. Practicality test covering 10 aspects of assessment is $80.31 \%$ with a practical category. While the lecturer's practicality test is $88,46 \%$ with a very practical category. Next is the result of student activity observation with a score of $90.0 \%$ with a very good category. Based on the explanation it can be concluded that online learning model based on effective and practical blended learning is used in increasing activity and learning outcomes. Furthermore, Chen (2007), with the overall results of the study being positive and significan ( $\mathrm{r}$ $=736)$, and the level of interaction and learning scores $(r=0.804)$ were also significant and positive. The results show that the level of interaction increases, the value of satisfaction and learning also increases. Then Opina (2014) conducted a study on the development and validity of online learning with the results of research that virtual learning environments have benefits for learning. $48.2 \%$ of 83 respondents prefer online education on campus; $46.8 \%$ more profitable on the online campus, while $6 \%$ has not been decided.

\section{Evaluation}

At this stage, an evaluation of the products developed from the design to the evaluation of learning. Evaluation in this study is validation from material experts, media experts, and linguists, as well as an assessment of learners. Based on learning outcomes by measuring the achievement of product development goals and measuring what has been achieved by the target.

Based on the description, it can be concluded that the online learning model based on blended learning has been practical, and can be used for the next testing stage, which is to test the effectiveness. Compare the test scores of students using online learning models based on blended learning and who do not use online learning model based on blended learning. The result obtained that the online learning model based on blended learning improves the comprehension of eye material of PTK and students' activity in the lecturing process.

\section{CONCLUSION}

Based on the result of the research, it can be concluded that the development of online learning model based on blended learning has fulfilled the criteria of valid and practical characteristics. A valid criterion that has fulfilled the online learning model based on blended learning that has been adapted to the characteristics of learning that contains the orientation of problem-solving from the learning that connects with the reality of the field, then the students will be directed to formulate the problems of the problems they find themselves. Practical criteria that meet the online learning model based on blended learning is the ease in the use of online learning model based on blended learning from the aspect of the implementation, ease of use and time required and on the online learning model provided online meetings to further improve student understanding. In addition, the online learning model also has a special space for a group discussion that will allow students to communicate with each other about solving problems that they find in the field. Online learning model based on blended learning is also effective in improving students' understanding ability in understanding the implementation of classroom action research. So it can be concluded that the online learning model has been produced based on blended learning that fulfills the valid, practical, and effective criteria to improve students' understanding on classroom action research (PTK).

Based on the conclusion, then the online learning model based on blended learning that is practical and effective and used in the learning can increase student activity and learning outcomes. online learning model based on blended learning is highly recommended in college learning that meet the requirements of online adequate. 


\section{References}

Alammary, S. C., et al (2014). Blended learning in higher education: Three different design. ASCILITE, 30 (4), $440-$ 454.

Chen, Y.-j. (2007). Effects of Online Interaction on Adult Students' Satisfaction. Journal Human Resource and Adult Learning, 3 (2), 78-89.

Ganefri. (2017). Seminar Nasional Teknologi Pendidikan. Padang: Universitas Negeri Padang.

Hastjarjo, S. (2009). Online Learning and Quality of Learning in Journalism Course. Jurnal Komunikasi Masa, 2 (2), 172-181.

Muchlas. (2013). Pengembangan Model Pembelajaran Online Untuk praktik Teknik Digital Di Perguruan Tinggi. Yogyakarta: UNY.

Nguyen, T. (2015). The Effectiveness of Online Learning: Beyond No Significant Difference and Future Horizons. MERLOT Journal of Online Learning and Teaching, 11 (2), 309-319.

Ni, A.Y. (2013). Comparing the Effectiveness of Classroom and Online Learning: Teaching Research Methods. Journal of Public Affairs Education, 19 (2), 199-215.

Opina. (2014) The Development And Validation Of Online Learning Modules For College English. American International Journal of Contemporary Research, 4 (2), 89-97.

Prawiradilaga, S, D. (2013). Mozaik Teknologi Pendidikan (E-Learning). Jakarta: Kencana.

Pribadi, B, A. (2010). Model Desain Sistem Pembelajaran. Jakarta: Dian Rakyat.

Republik Indonesia. (2003). Undang-undang N0.20 Tahun 2003 tentang standar pendidikan nasional. Sekretariat Negara: Jakarta.

Republik Indonesia. (2013). Peraturan pemerintah No. 32 Tahun 2013 tentang standar nasional pendidikan. Sekretariat Negara: Jakarta.

Tiara. (2015). Pengembangan media e-learning berbasis moodle pada kompetensi dasar jurnal khusus untuk siswa Kelas XII IPS Semester Gasal di SMA Negeri 4 Jember. Surakarta: USM.

Universitas Negeri Padang. (2018). Penilaian Hasil Belajar. Diperoleh 15 Maret 2018 dari http://.unp.ac.id

Wulandari. (2014). Pengembangan Desain Media Pembelajaran Online Berbasis Aplikasi Prezi pada Standar Kompetensi Korespondensi Bahasa Indonesia SMK Kompetensi Keahlian Administrasi Perkantoran. Yogyakarta: UNY 